\title{
Efficacy of several biological therapies for treating moderate to severe psoriasis: A network meta-analysis
}

\author{
WENJUN GENG, JIANHUA ZHAO, JIXING FU, HUAMIN ZHANG and SHAOHUA QIAO
}

Department of Dermatology, The Second Hospital of Liaocheng, Linqing, Shandong 252601, P.R. China

Received December 8, 2015; Accepted December 19, 2016

DOI: $10.3892 /$ etm.2018.6859

\begin{abstract}
The aim of the present meta-analysis was to systematically assess the efficacy of the various treatments available for moderate to severe psoriasis. PubMed and Embase databases were systematically searched to select relevant studies up to February 2015. Odds ratios (ORs) and their 95\% confidence intervals (CIs) were used as effect estimates. In addition, the Psoriasis Area and Severity Index (PASI) 50, PASI 75 and PASI 90 responses for the therapies were systematically assessed. A total of 33 randomized controlled trials were included in the present study. For the PASI 75 response rate, infliximab $(5 \mathrm{mg})$ may be the most effective option for the treatment of moderate to severe psoriasis. Furthermore, the pooled results of the PASI 50 response rate demonstrated that infliximab $(5 \mathrm{mg})$ and ustekinumab (90 mg) may be superior to other drugs for treating moderate to severe psoriasis. For the PASI 90 response rate, infliximab (5 mg), ustekinumab (90 mg) and briakinumab (weeks 0 and 4, $200 \mathrm{mg}$; week 8, $100 \mathrm{mg}$ ) exhibited improved results compared with other treatments. In conclusion, infliximab $(5 \mathrm{mg})$ may be a superior option to treat moderate to severe psoriasis due to the relatively high PASI scores. However, despite the high PASI 90 responses, further studies are required to identify the efficacy of ustekinumab (90 mg) and briakinumab.
\end{abstract}

\section{Introduction}

Psoriasis is a common immune-mediated skin disease. The prevalence of psoriasis in adults ranges between 0.91 and $8.5 \%$ worldwide and the incidence of psoriasis is higher in adults than in children (1). Psoriasis is characterized by symptoms of plaque, pustular and other skin lesions. Chronic plaque psoriasis accounts for $90 \%$ of all psoriasis cases $(2,3)$.

Correspondence to: Dr Wenjun Geng, Department of Dermatology, The Second Hospital of Liaocheng, 306 Jiankang Street, Linqing, Shandong 252601, P.R. China

E-mail: wenjungeng@126.com

Key words: biological therapies, psoriasis, Psoriasis Area and Severity Index, network meta-analysis
A number of biological therapies are used to treat moderate to severe psoriasis, including etanercept, briakinumab, ustekinumab, adalimumab and infliximab (4-8). Etanercept, adalimumab and infliximab are monoclonal antibodies against tumor necrosis factor (TNF), which function by neutralizing the biological activity of TNF for treating the TNF-mediated inflammation $(5,9)$. By contrast, ustekinumab and briakinumab are human monoclonal antibodies against interleukin (IL)-12/23p40 (8). These biological therapies are used to treat psoriasis and improved clinical outcomes have been observed. However, the efficacy of these therapies has been not systematically reviewed.

In the present study, a network meta-analysis was performed to review and compare the efficacy of these aforementioned biological therapies of psoriasis. The Psoriasis Area and Severity Index (PASI) response (10) was used as an indicator for assessing the effect of treatment on the severity of psoriasis. PASI 50, PASI 75 and PASI 90 responses for the therapies were systematically assessed. The pooled results provide further information on selecting the most suitable treatments for moderate to severe psoriasis.

\section{Materials and methods}

Data sources. The PubMed (www.ncbi.nlm.nih.gov/pubmed) and Embase (www.elsevier.com/solutions/embase-biomedical-research) databases were systematically searched in order to select relevant studies up to February 2015. The search terms included the following: Psoriasis, methotrexate (MTX), cyclosporin A (CSA), ustekinumab, etanercept, infliximab, briakinumab and adalimumab.

Inclusion and exclusion criteria. Studies with the following characteristics were included in the current meta-analysis: i) Randomized controlled trials (RCTs) reporting the treatment of moderate to severe psoriasis with the aforementioned drugs. Moderate to severe psoriasis is defined as body surface area $>10$ or psoriasis area and severity index $>10$ and dermatology life quality index $>10$ (11); ii) studies including the adults as participants; and iii) studies reporting the PASI response rate (50, 75 and 90\%). Any reviews, case reports and letters were excluded from the meta-analysis. Any studies investigating patients with mild psoriasis and those written in a language other than English were also excluded. 
Data extraction and quality assessment. Two reviewers independently extracted the following data: The name of the first author, publication year, sample size, intervention, demographic characteristics of the included patients and PASI response rate. The controversies were discussed with a third reviewer to reach consensus. The methodological quality of the included studies was evaluated by the Cochrane Collaboration Risk of Bias Tool (12).

Statistical analysis. All analyses were performed using the ADDIS software version 1.16.5 (Drug Information and Monitoring Systems, Groningen, The Netherlands). Odds ratios (ORs) and their 95\% confidence intervals (CIs) were pooled. The network analysis performed was based on the Bayesian framework. Data were evaluated by Markov chain Monte Carlo methods and all analyses were performed using the random effects model. The consistency of the RCTs was assessed by Node-splitting analysis, and the consistency model was used if $\mathrm{P}>0.05$. Otherwise, the inconsistency model was used to pool the odd ratios (13).

\section{Results}

Study selection. As presented in Fig. 1, a total of 897 studies were identified from PubMed and 917 studies from Embase by the initial search. Subsequent to excluding any duplicates, 1,113 studies remained. A total of 831 irrelevant studies were excluded by reviewing the titles and abstracts. In addition, 249 studies that did not meet the inclusion criteria were excluded. Finally, 33 RCTs were included in the present study $(4-9,14-40)$.

Characteristics of the included studies. As presented in Table I, the demographic characteristics, including age, sex and weight of the patients in the included studies were similar. Included RCTs were published between 1994 and 2015. The mean duration of psoriasis of the included patients ranged between 11.1 and 21.5 years. Quality assessment demonstrated that the quality of the included RCTs was relatively high. With respect to random sequence generation (selection bias), a number of studies were assessed as having an unclear risk of bias. With regards to blinding of participants and personnel (performance bias), blinding of outcome assessment (detection bias) and incomplete outcome data (attrition bias), a small proportion of studies were assessed as having high risk of bias (Fig. 2) and were excluded from the current study. However, the studies by Laburte et al (25) and Cassano et al (15) were not excluded as they met with the inclusion criteria despite having quite a poor rating.

Network meta-analysis. Based on the results of node-splitting analysis (Table II), the effect sizes were pooled using an inconsistency model. Regarding the PASI 75 response rate, infliximab $(5 \mathrm{mg}$ ) was the most effective option for the treatment of moderate to severe psoriasis (Table III and Fig. 3). The pooled results of the PASI 50 response rate demonstrated that infliximab (5 mg) and ustekinumab (90 mg) may be superior to other drugs for treating moderate to severe psoriasis (Table IV). In addition, regarding the PASI 90 response rate, treatment with infliximab $(5 \mathrm{mg})$, ustekinumab

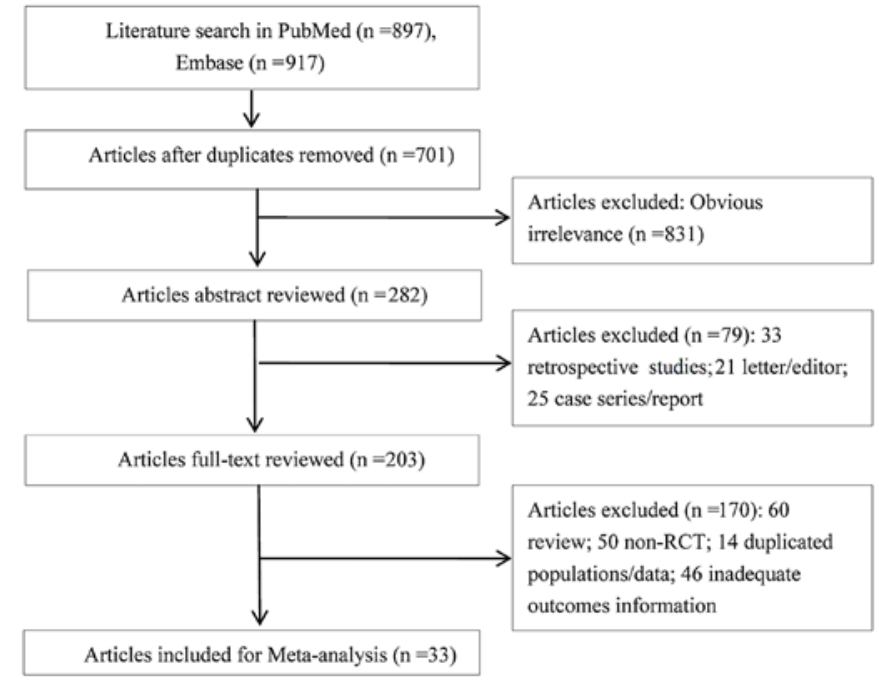

Figure 1. Process of the literature selection performed in the present meta-analysis. RCT, randomized controlled trial.

(90 mg) and briakinumab (weeks 0 and 4, $200 \mathrm{mg}$; week 8 , $100 \mathrm{mg}$ ) indicated improved results compared with other agents (Table V). Finally, the drugs can be ranked in the following order according to their efficacy, defined as their PASI 90 response rate: Briakinumab $>$ ustekinumab $(90 \mathrm{mg})$ $>$ infliximab $(5 \mathrm{mg})>$ ustekinumab $(45 \mathrm{mg})>$ adalimumab $>$ infliximab $(3 \mathrm{mg})>$ etanercept $(50 \mathrm{mg}$ BIW $)>\operatorname{CSA}(5 \mathrm{mg})>$ etanercept $(25 \mathrm{mg}$ BIW) $>$ MTX $>$ etanercept $(25 \mathrm{mg} \mathrm{QW})>$ placebo (Table VI). The odds ratio value of infliximab $(5 \mathrm{mg}$ ) compared with the other drugs was $>1$, therefore, infliximab $(5 \mathrm{mg})$ was regarded as the best treatment agent, although it ranked as third in terms of efficacy.

\section{Discussion}

In the present study, a network meta-analysis was performed to systematically review and compare the efficacy of seven drugs used at different doses for treating moderate to severe psoriasis. Based on the results of the network analysis, infliximab (5 mg) may be an appropriate option to treat moderate to severe psoriasis.

Psoriasis has been reported to be associated with a high concentration of TNF- $\alpha$ (41) and infliximab treatment can neutralize the biological activity of TNF- $\alpha$ (42). However, the role of the TNF- $\alpha$ in the pathogenesis of psoriasis remains unclear. Previous studies have reported that TNF- $\alpha$ may serve an important role in the upstream of the inflammatory responses of psoriasis $(43,44)$. An in vitro study determined that infliximab was able to inhibit the activation of skin-homing $\mathrm{T}$ cells and impair the antigen-presenting capacity of immature dendritic cells in psoriasis patients (43). However, another TNF- $\alpha$ inhibitor, etanercept, has been found to be effective in the treatment of psoriasis by reducing the Th17 cell products, as well as the production of IL-17, IL-22, IL-23 and inducible NO synthase from dendritic cells (44). Thus, it has been suggested that the infliximab may serve a different role with other treatments on moderate to severe psoriasis.

Although the present meta-analysis indicated that infliximab treatment had a high PASI score, a higher percentage 


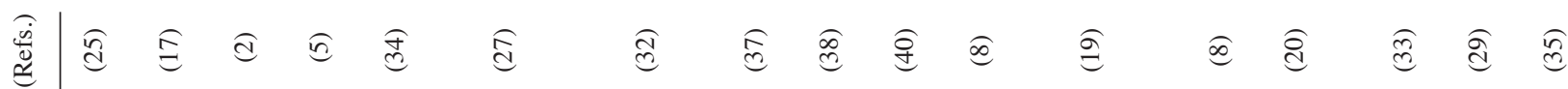

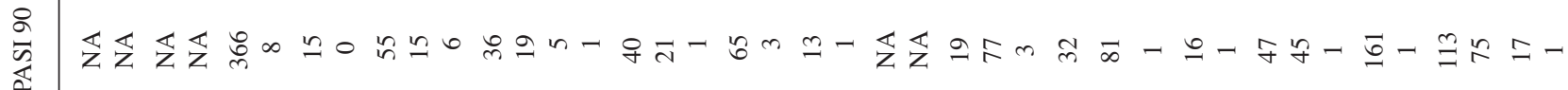

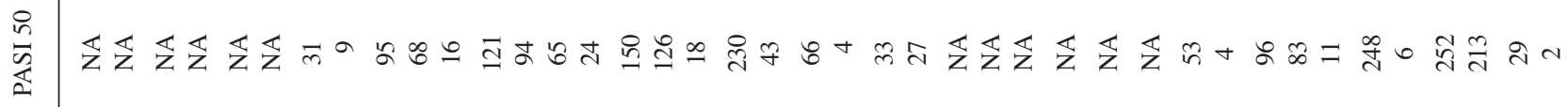

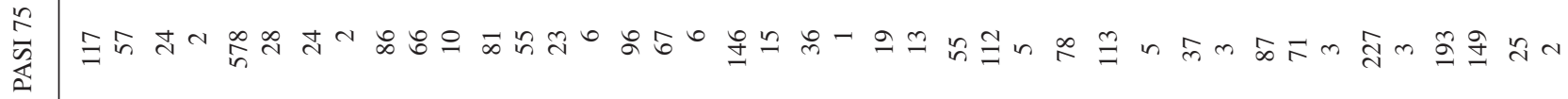

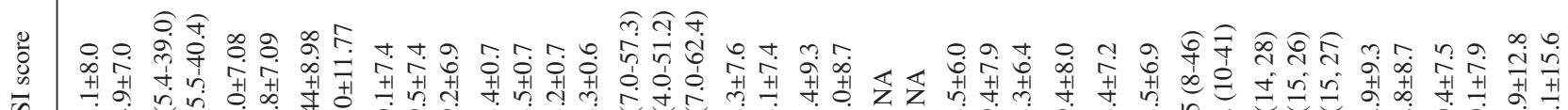

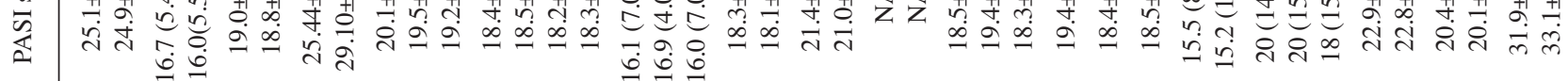

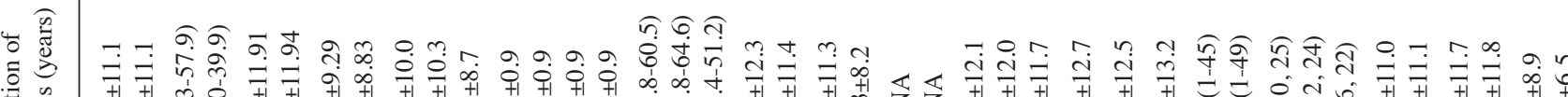

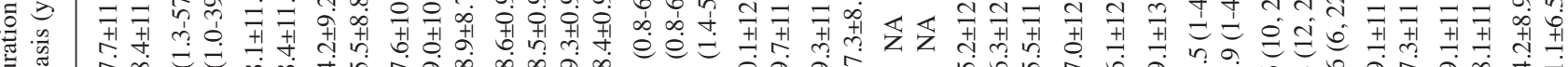

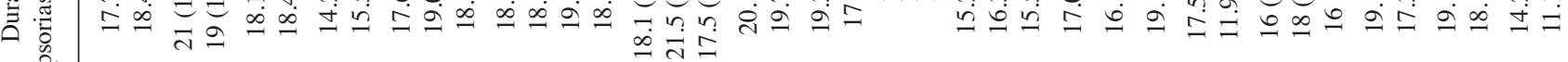

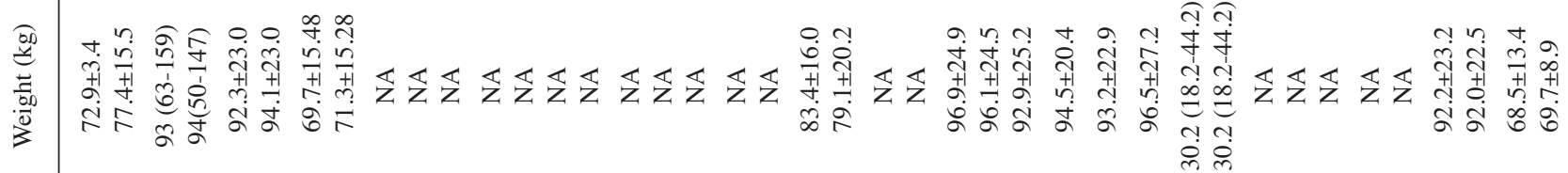

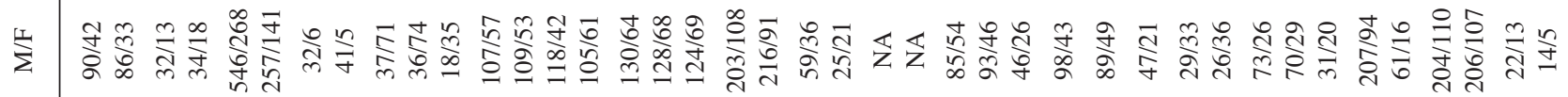

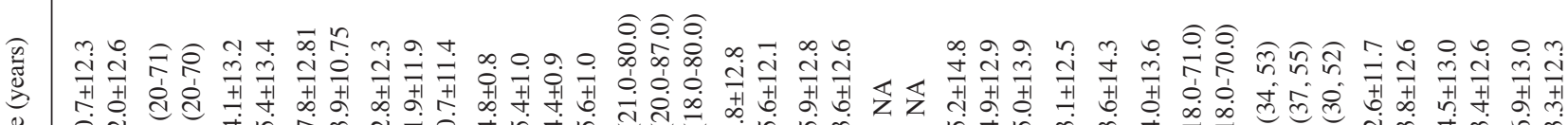

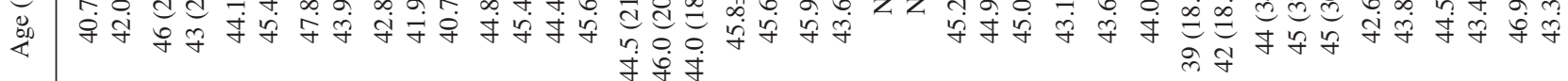

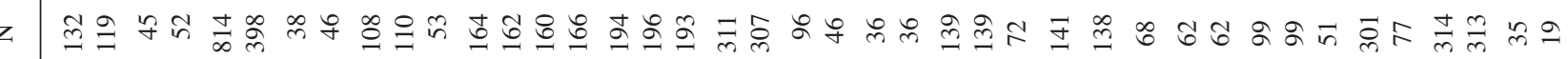

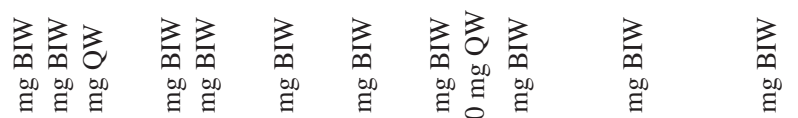

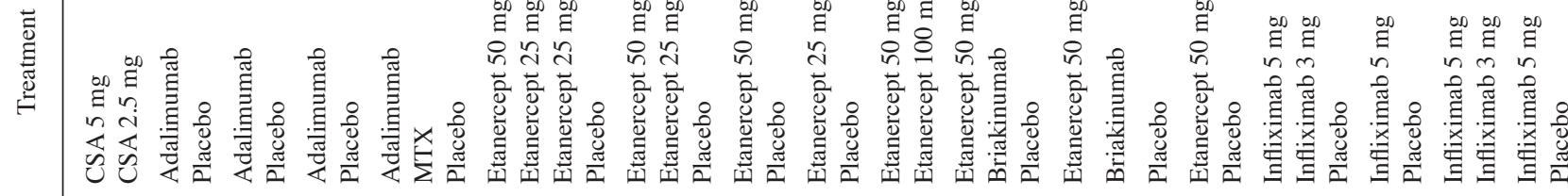

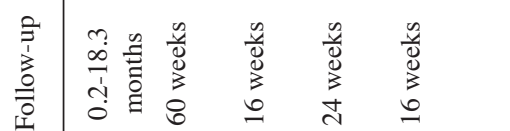

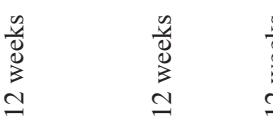

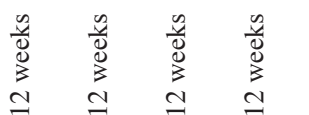

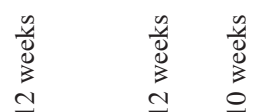

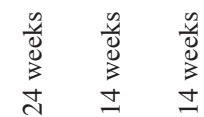

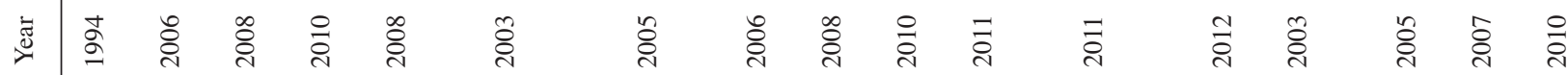




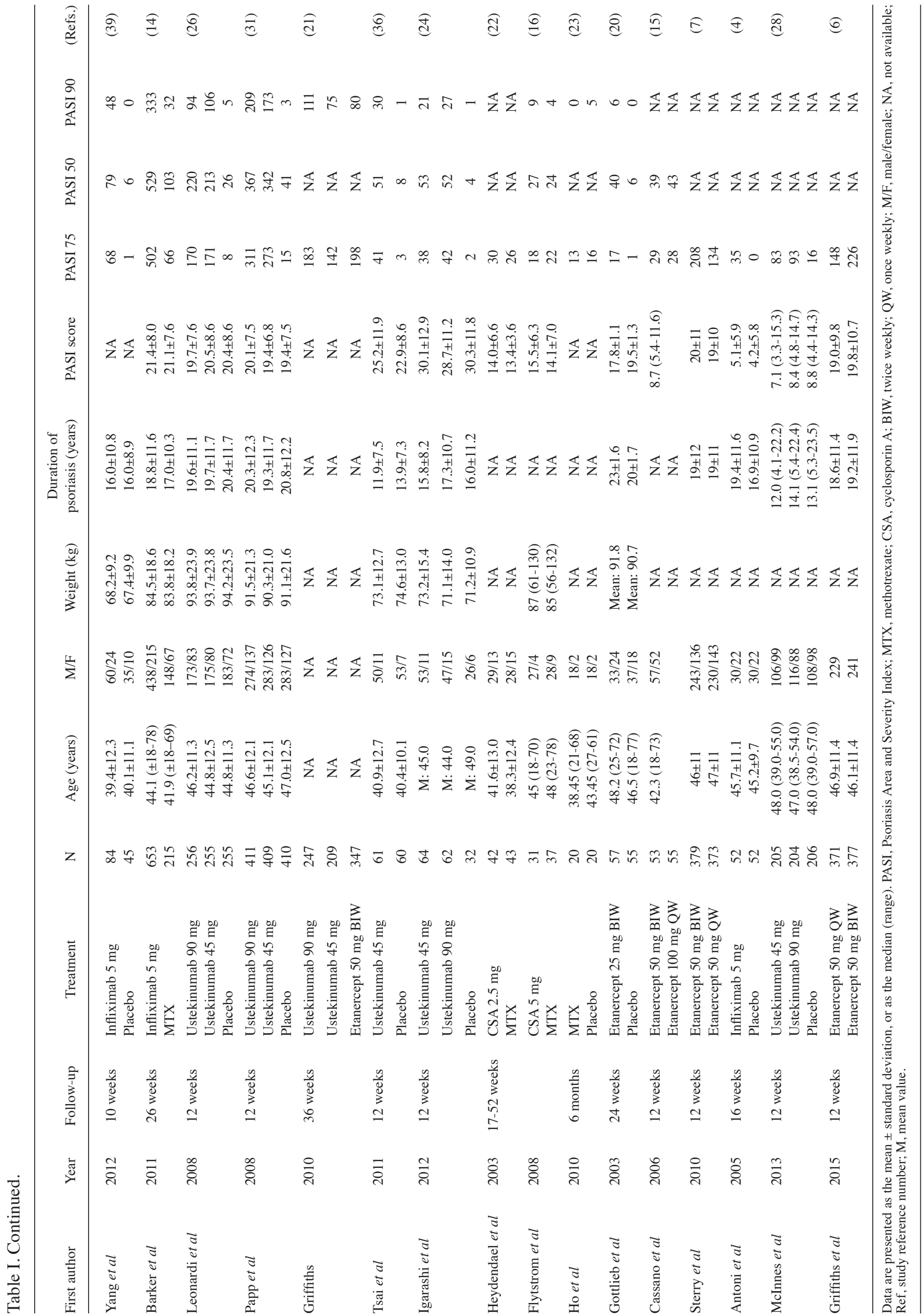


Table II. Node-splitting analysis.

\begin{tabular}{|c|c|c|c|c|}
\hline Name & Direct effect & Indirect effect & Overall & P-value \\
\hline \multicolumn{5}{|l|}{ PASI 75} \\
\hline Adalimumab, MTX & $-1.03(-2.13,0.09)$ & $-0.13(-1.44,1.31)$ & $-0.81(-1.64,0.10)$ & 0.28 \\
\hline CSA $2.5 \mathrm{mg}$, CSA $5 \mathrm{mg}$ & $2.15(1.15,3.13)$ & $-0.55(-2.24,1.08)$ & $1.47(0.44,2.41)$ & 0.01 \\
\hline CSA $2.5 \mathrm{mg}$, MTX & $-0.51(-1.71,0.64)$ & $2.24(0.71,3.77)$ & $0.46(-0.62,1.48)$ & 0.01 \\
\hline CSA 5 mg, MTX & $0.02(-1.18,1.24)$ & $-2.70(-4.23,-1.12)$ & $-1.01(-2.06,0.07)$ & 0.01 \\
\hline $\begin{array}{l}\text { Etanercept } 25 \mathrm{mg} \text { BIW, } \\
\text { Etanercept } 50 \mathrm{mg} \text { BIW }\end{array}$ & $0.64(-0.08,1.35)$ & $-0.05(-1.03,0.89)$ & $0.41(-0.27,1.01)$ & 0.23 \\
\hline Etanercept 50 mg BIW, Placebo & $-3.02(-3.57,-2.49)$ & $-3.18(-4.11,-2.32)$ & $-3.03(-3.51,-2.58)$ & 0.74 \\
\hline $\begin{array}{l}\text { Etanercept } 50 \mathrm{mg} \text { BIW, } \\
\text { Ustekinumab } 45 \mathrm{mg}\end{array}$ & $0.46(-0.61,1.51)$ & $0.51(-0.19,1.18)$ & $0.48(-0.15,1.08)$ & 0.9 \\
\hline $\begin{array}{l}\text { Etanercept } 50 \mathrm{mg} \text { BIW, } \\
\text { Ustekinumab } 90 \mathrm{mg}\end{array}$ & $0.77(-0.29,1.80)$ & $0.54(-0.20,1.20)$ & $0.62(-0.00,1.23)$ & 0.69 \\
\hline Infliximab $3 \mathrm{mg}$, Placebo & $-3.86(-5.56,-2.35)$ & $-3.95(-5.09,-2.86)$ & $-3.95(-4.95,-3.01)$ & 0.94 \\
\hline Infliximab 5 mg, MTX & $-2.01(-3.06,-1.04)$ & $-2.18(-3.45,-0.84)$ & $-2.08(-2.86,-1.25)$ & 0.83 \\
\hline Infliximab $5 \mathrm{mg}$, Placebo & $-4.83(-5.77,-4.02)$ & $-4.65(-6.16,-3.25)$ & $-4.73(-5.50,-4.08)$ & 0.81 \\
\hline MTX, Placebo & $-2.53(-3.72,-1.49)$ & $-2.70(-3.69,-1.78)$ & $-2.66(-3.50,-1.92)$ & 0.81 \\
\hline Placebo, Ustekinumab $45 \mathrm{mg}$ & $3.54(2.96,4.11)$ & $3.44(2.39,4.44)$ & $3.52(2.99,4.02)$ & 0.83 \\
\hline Placebo, Ustekinumab $90 \mathrm{mg}$ & $3.60(2.97,4.18)$ & $3.83(2.83,4.83)$ & $3.65(3.11,4.17)$ & 0.65 \\
\hline \multicolumn{5}{|l|}{ PASI 50} \\
\hline Adalimumab, MTX & $-1.51(-2.41,-0.70)$ & $0.04(-1.06,1.18)$ & $-1.10(-2.03,-0.21)$ & 0.02 \\
\hline $\begin{array}{l}\text { Etanercept } 25 \mathrm{mg} \text { BIW, } \\
\text { Etanercept } 50 \mathrm{mg} \text { BIW }\end{array}$ & $0.64(-0.05,1.38)$ & $0.73(-0.20,1.76)$ & $0.61(0.02,1.21)$ & 0.88 \\
\hline Etanercept $50 \mathrm{mg}$ BIW, Placebo & $-3.13(-3.66,-2.70)$ & $-3.82(-4.93,-2.73)$ & $-3.22(-3.78,-2.75)$ & 0.24 \\
\hline Infliximab $3 \mathrm{mg}$, Placebo & $-3.11(-4.31,-1.87)$ & $-2.93(-4.01,-1.89)$ & $-3.04(-3.92,-2.25)$ & 0.82 \\
\hline Infliximab 5 mg, MTX & $-1.54(-2.19,-0.88)$ & $-3.08(-4.17,-2.09)$ & $-2.02(-2.88,-1.37)$ & 0.01 \\
\hline Infliximab $5 \mathrm{mg}$, Placebo & $-4.45(-5.18,-3.92)$ & $-2.93(-3.90,-1.90)$ & $-4.13(-4.79,-3.55)$ & 0.01 \\
\hline MTX, Placebo & $-1.42(-2.34,-0.45)$ & $-2.57(-3.39,-1.73)$ & $-2.11(-2.85,-1.31)$ & 0.06 \\
\hline \multicolumn{5}{|l|}{ PASI 90} \\
\hline Adalimumab, MTX & $-2.04(-3.04,-0.99)$ & $-0.49(-1.91,0.86)$ & $-1.67(-2.58,-0.81)$ & 0.08 \\
\hline $\begin{array}{l}\text { Etanercept } 25 \mathrm{mg} \text { BIW, } \\
\text { Etanercept } 50 \mathrm{mg} \text { BIW }\end{array}$ & $0.86(0.14,1.62)$ & $-0.03(-1.47,1.35)$ & $0.75(0.04,1.39)$ & 0.24 \\
\hline Etanercept 50 mg BIW, Placebo & $-3.15(-3.90,-2.45)$ & $-3.34(-4.48,-2.42)$ & $-3.16(-3.78,-2.63)$ & 0.76 \\
\hline $\begin{array}{l}\text { Etanercept } 50 \mathrm{mg} \text { BIW, } \\
\text { Ustekinumab } 45 \mathrm{mg}\end{array}$ & $0.63(-0.36,1.70)$ & $0.99(0.12,1.83)$ & $0.82(0.19,1.48)$ & 0.53 \\
\hline $\begin{array}{l}\text { Etanercept } 50 \mathrm{mg} \text { BIW, } \\
\text { Ustekinumab } 90 \mathrm{mg}\end{array}$ & $1.00(0.01,2.02)$ & $0.73(-0.10,1.59)$ & $0.90(0.22,1.52)$ & 0.61 \\
\hline Infliximab $3 \mathrm{mg}$, Placebo & $-4.12(-8.54,-2.14)$ & $-3.54(-4.91,-2.48)$ & $-3.56(-4.64,-2.64)$ & 0.69 \\
\hline Infliximab $5 \mathrm{mg}$, MTX & $-1.80(-2.74,-0.87)$ & $-2.98(-4.73,-1.47)$ & $-2.07(-2.97,-1.38)$ & 0.18 \\
\hline Infliximab 5 mg, Placebo & $-4.46(-6.00,-3.43)$ & $-3.33(-4.77,-2.10)$ & $-3.93(-4.80,-3.18)$ & 0.2 \\
\hline MTX, Placebo & $-1.24(-2.38,-0.25)$ & $-2.30(-3.43,-1.40)$ & $-1.85(-2.60,-1.07)$ & 0.12 \\
\hline Placebo, Ustekinumab $45 \mathrm{mg}$ & $4.15(3.45,4.86)$ & $3.78(2.83,4.68)$ & $3.99(3.37,4.61)$ & 0.37 \\
\hline Placebo, Ustekinumab 90 mg & $3.99(3.22,4.77)$ & $4.32(3.40,5.28)$ & $4.07(3.40,4.70)$ & 0.44 \\
\hline
\end{tabular}

PASI, Psoriasis Area and Severity Index; MTX, methotrexate; CSA, cyclosporin A; BIW, twice weekly; QW, once weekly.

of adverse events were observed in infliximab-treated patients compared with those in the placebo group (18), indicating that infliximab treatment induces adverse effects. In addition, infliximab treatment increases the incidence of infusion reactions (45). However, these outcomes were not considered to be important due to the small sample size of each study or the fact that the data were unavailable. Thus, the therapeutic effect of the infliximab should be systematically assessed in further studies. Besides, the dosage and treatment duration of infliximab should be optimized according to the disease severity of psoriasis.

In the present study, briakinumab and ustekinumab (90 mg) treatments were superior to other treatments for PASI 90 response. Thus, anti-IL-12/23 monoclonal antibodies appear to be more appropriate compared with anti-TNF- $\alpha$ treatment for treating moderate to severe psoriasis. However, briakinumab and ustekinumab showed no significantly improved therapeutic effect in PASI 75 and PASI 50 responses when compared with the anti-TNF- $\alpha$ treatments. In addition, the long-term safety profile, including severe infections and cardiac disorders, should be evaluated in further studies with large sample sizes and strict study design.

To the best of our knowledge, the present study is the first network meta-analysis for evaluating the efficacy of various treatments for moderate to severe psoriasis. The current results may provide information for clinician and patients on the selection of the suitable treatment for moderate to severe psoriasis. However, there were also several limitations in the present meta-analysis. Firstly, due to unavailable data in certain included studies, confounding variables could not be adjusted and subgroup analysis was not performed to reduce the effect 

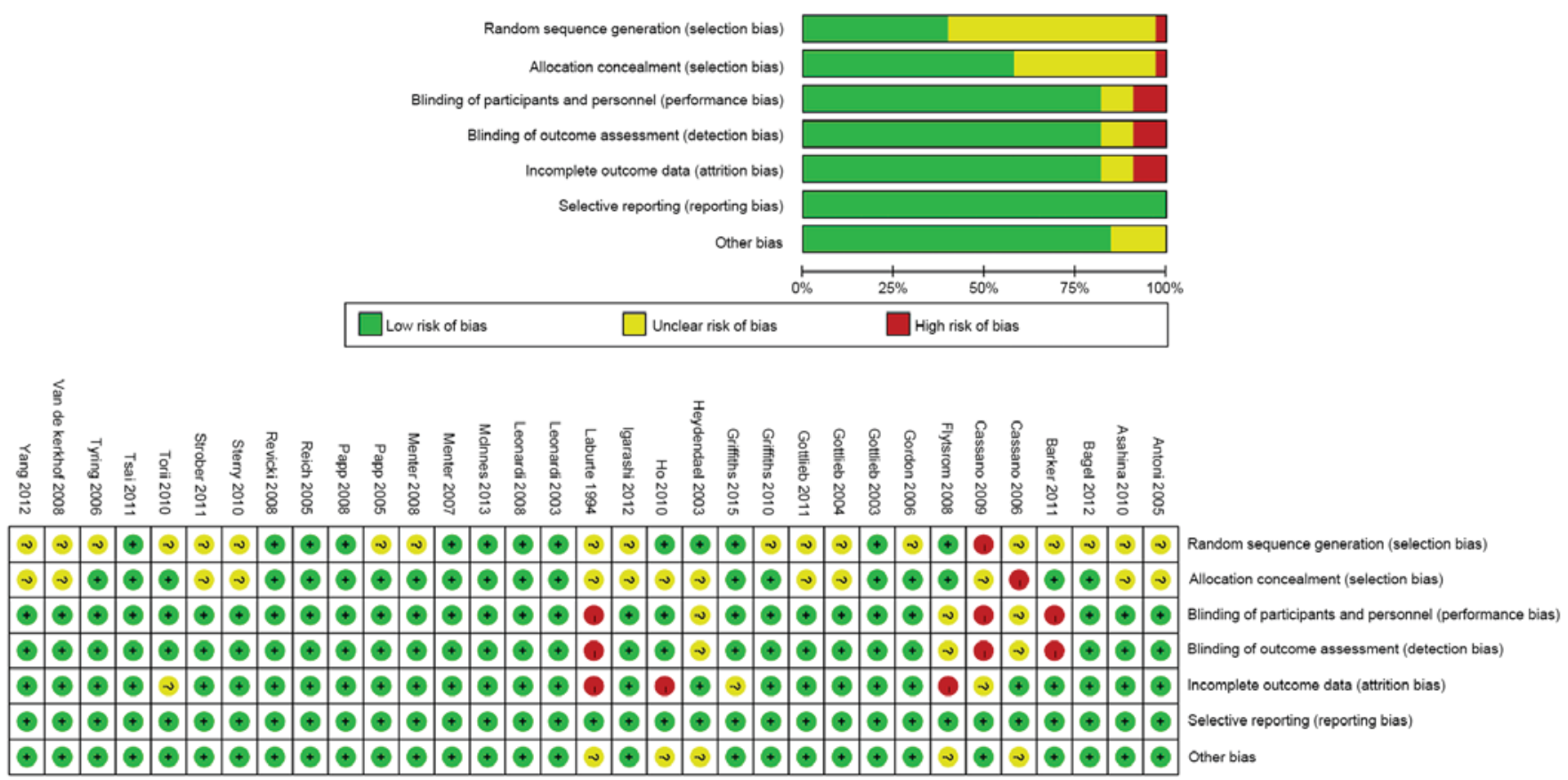

Figure 2. Risk of bias of the included studies. +, low risk of bias; ?, unclear risk of bias; -, high risk of bias. The quality evaluation map indicates that, regarding random sequence generation (selection bias) and allocation concealment (selection bias), many references have an unclear risk of bias and few references have high risk of bias. However, regarding incomplete outcome data (attrition bias), blinding of participants and personnel (performance bias) and blinding of outcome assessment (detection bias), 10\% references have high risk of bias and 10\% references have an unclear risk of bias. The included references showed no evidence of selective reporting (reporting bias) in the included references-all references showed a low risk of bias.

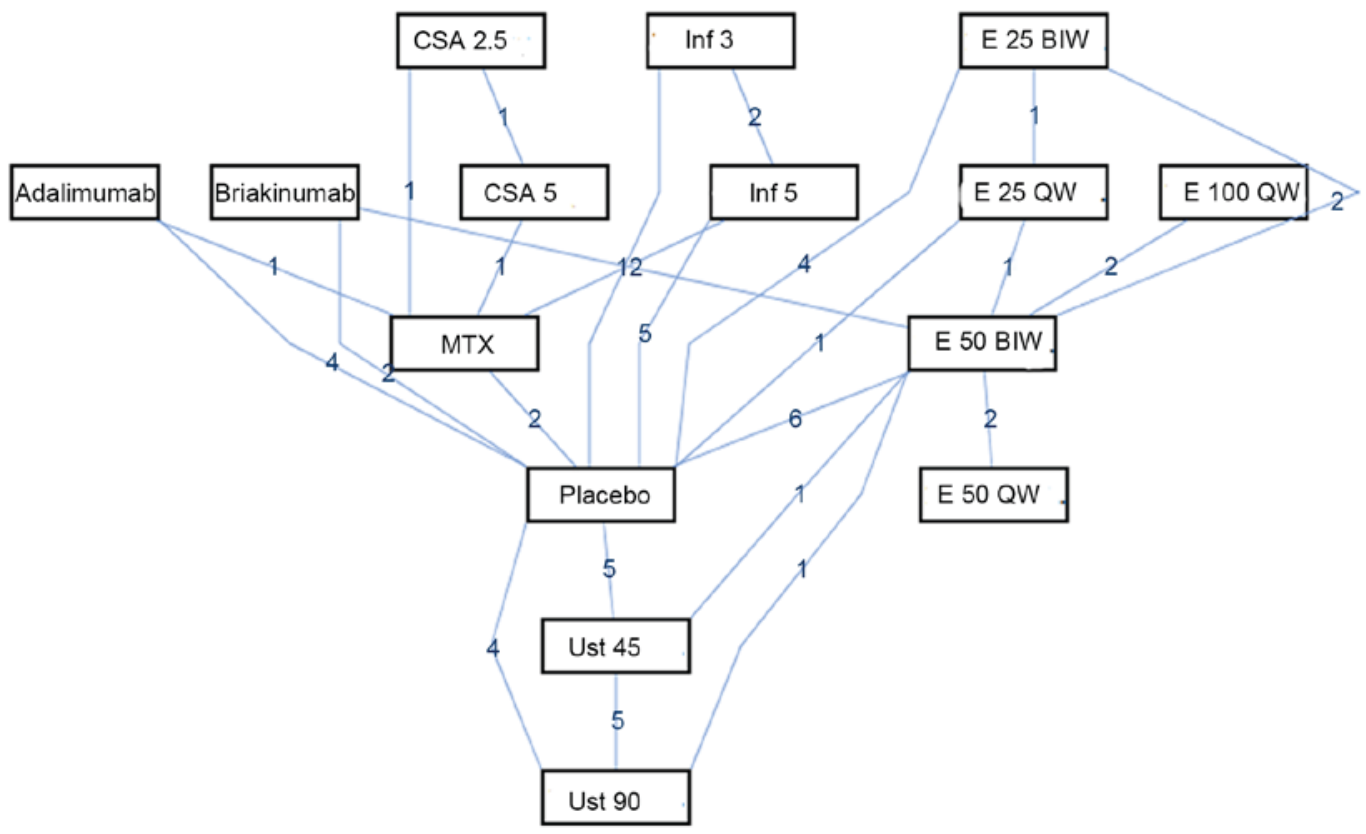

Figure 3. Network of PASI 75 response rate. The figures on the blue edges refer to the comparison times. PASI, Psoriasis Area and Severity Index. Image generated using ADDIS software 1.16.5.

of the confounding variables. Secondly, due to unknown bias, the network analyses of PASI 75 and PASI 50 responses were performed using an inconsistency model. Finally, the results of the network meta-analysis should be pooled only by a random effects model. Thus, the pooled results may be conservative and certain borderline significant effects may have been ignored (46).
In conclusion, the present meta-analysis results suggested that infliximab (5 mg) may be a superior option compared with other drugs for treating moderate to severe psoriasis due to the relatively high PASI scores of patients. However, despite the high PASI 90 responses, the efficacy of ustekinumab $(90 \mathrm{mg})$ and briakinumab were also high and therefore should be investigated in further studies. 


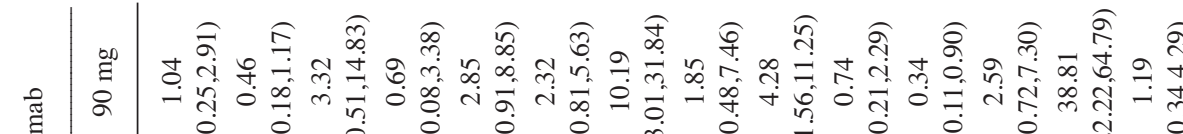

爱

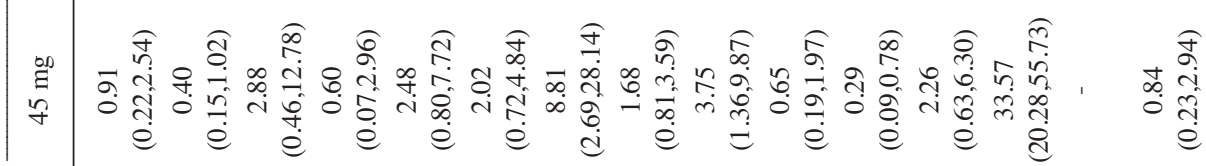

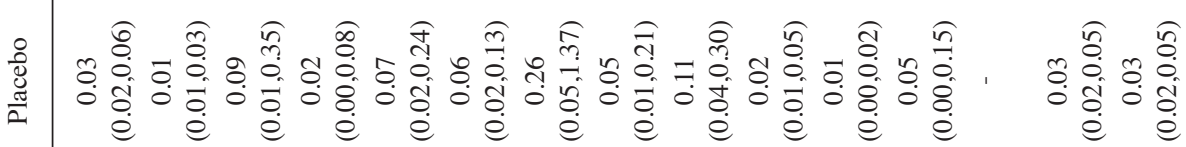

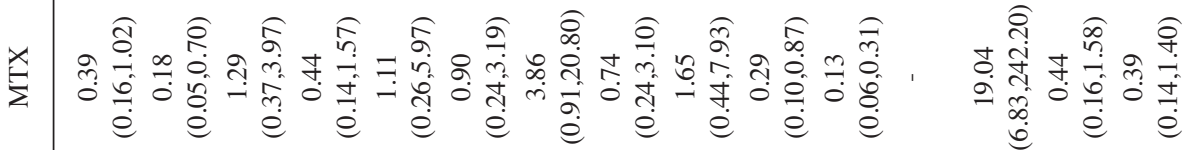

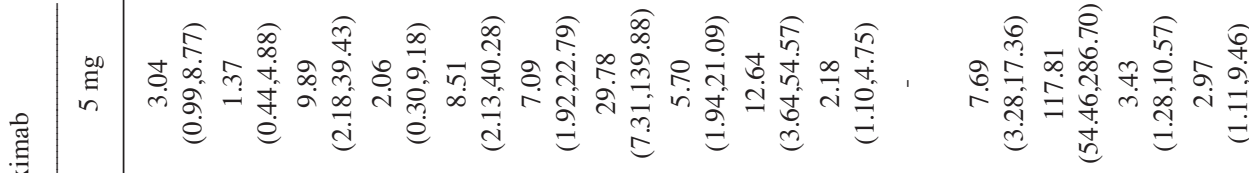

沯

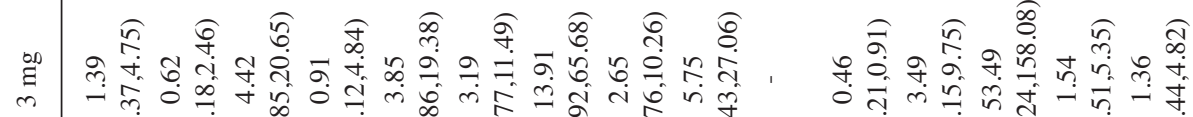

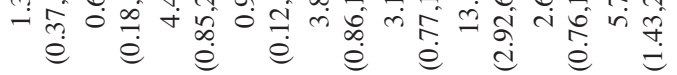

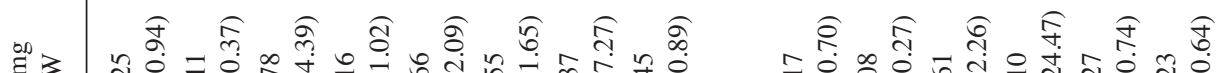

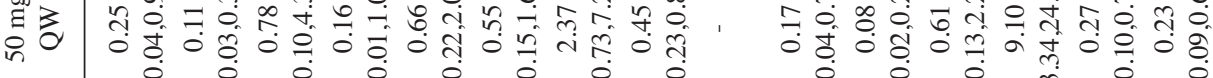

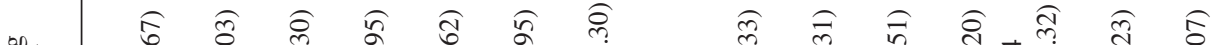

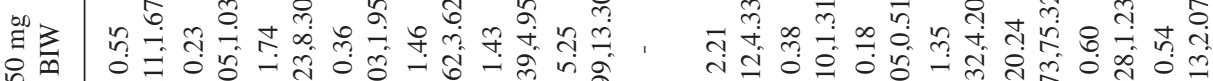

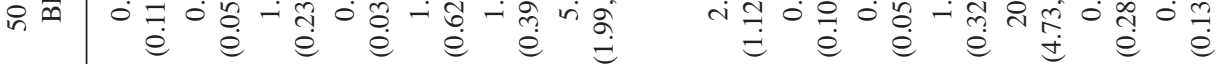

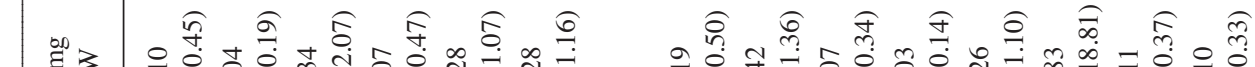

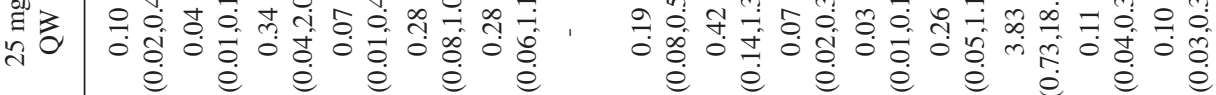

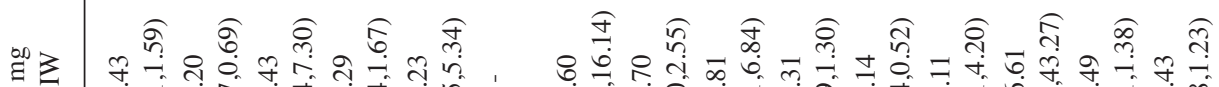

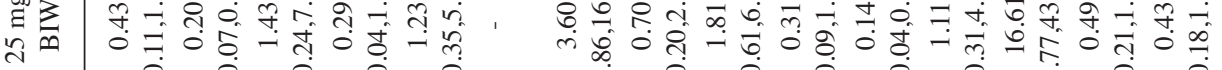

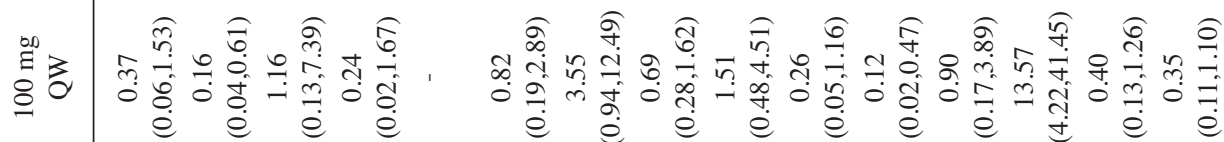

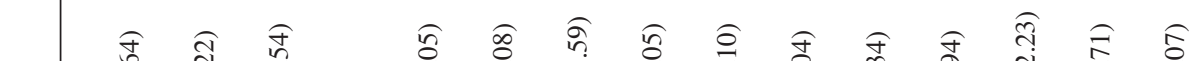

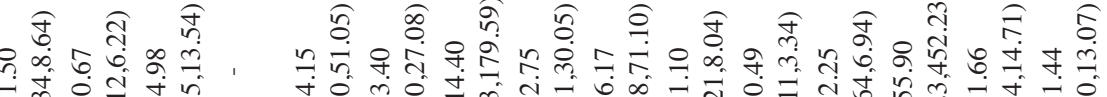

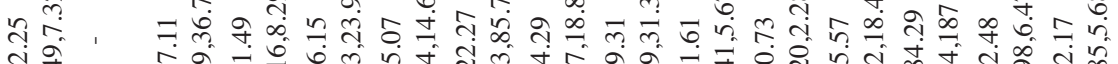

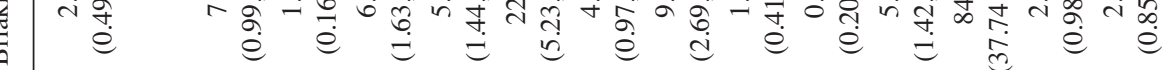

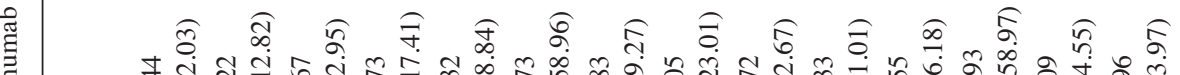

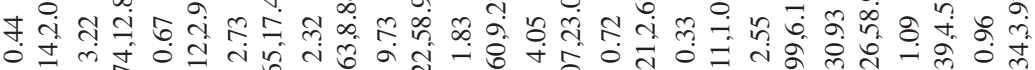

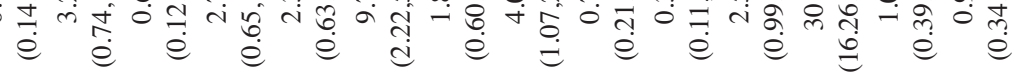
营

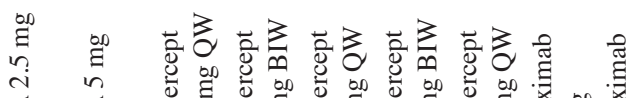

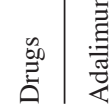

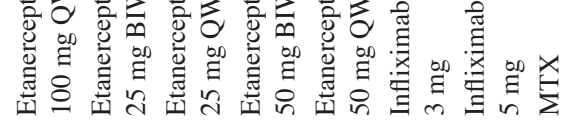




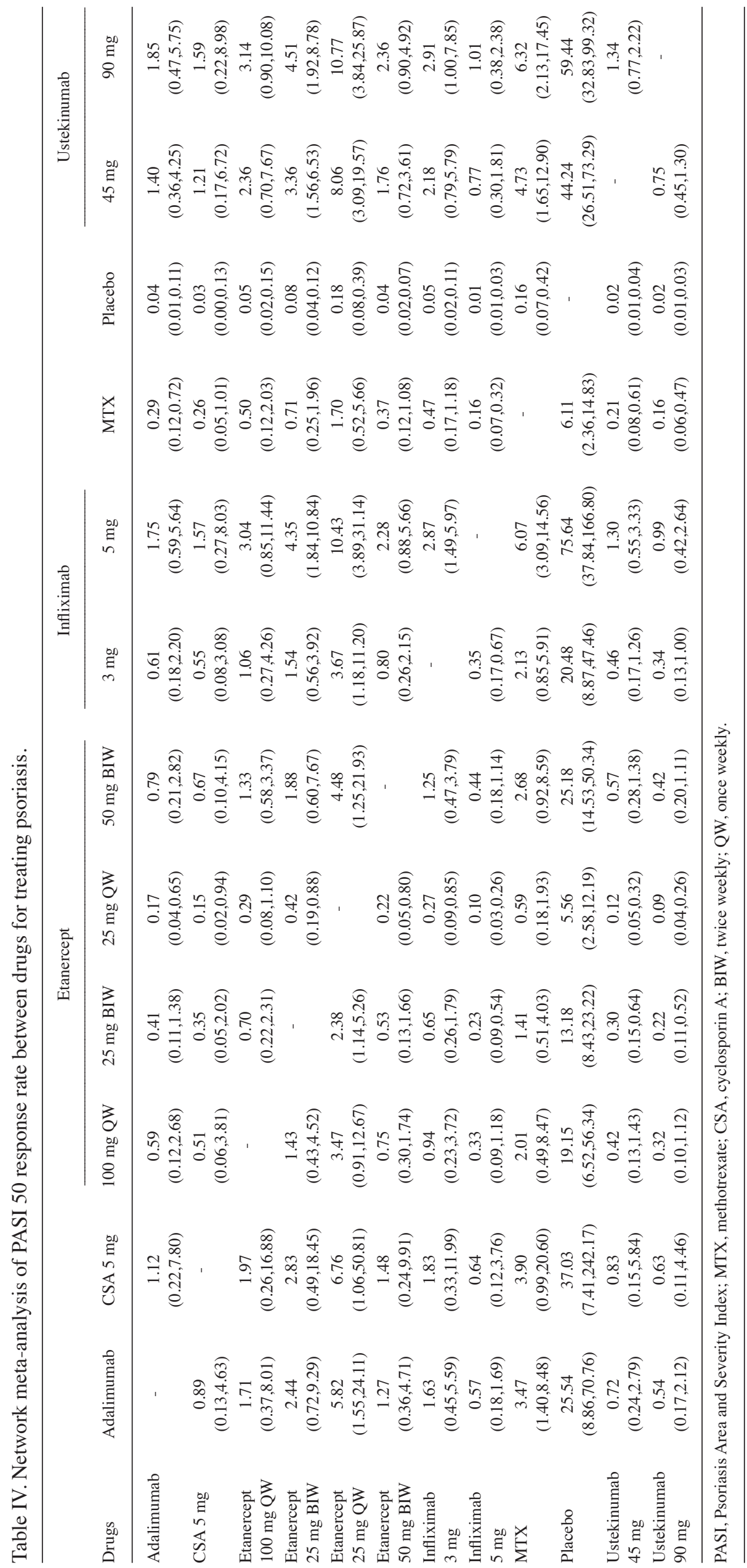




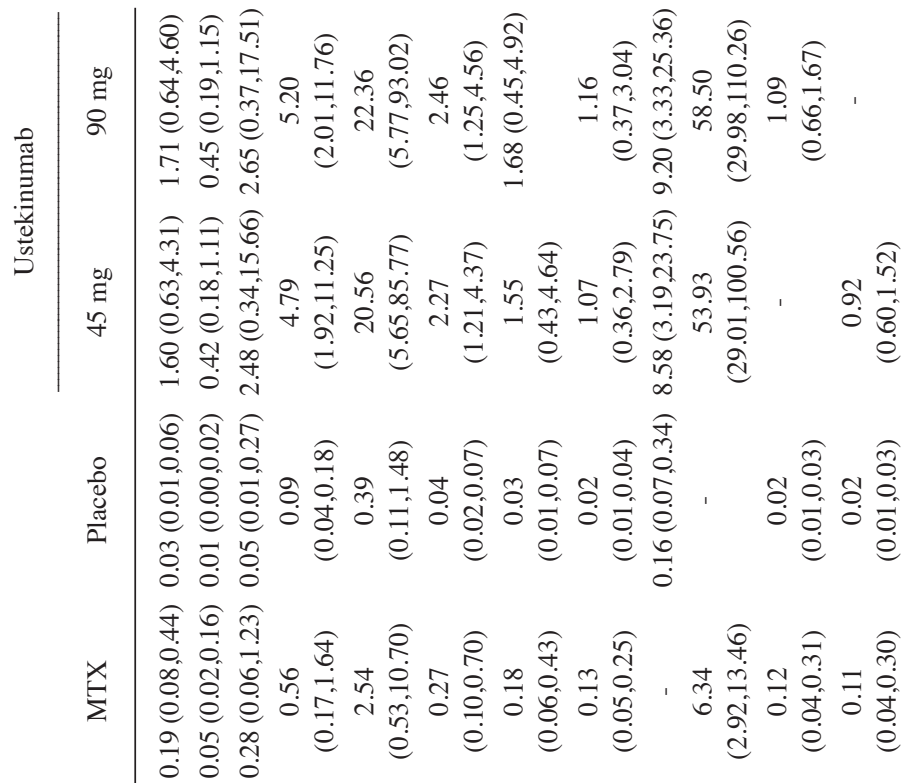

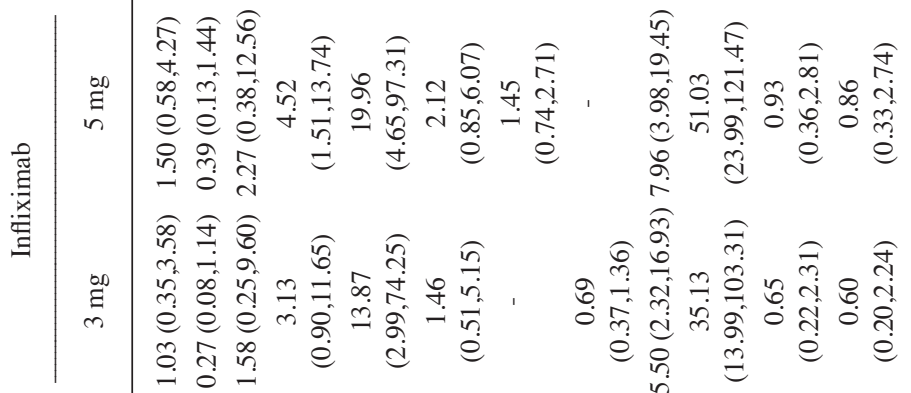
政

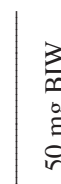

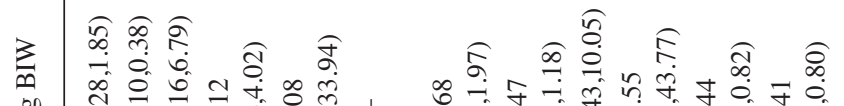

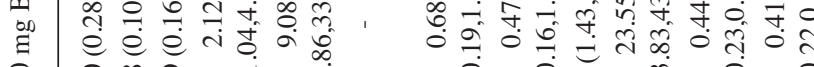
in

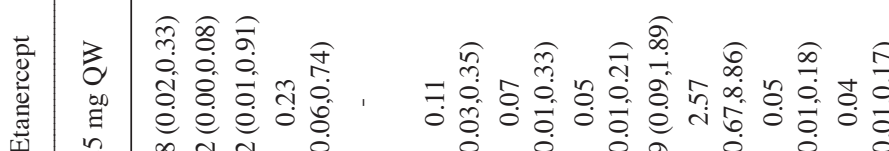

용 궁

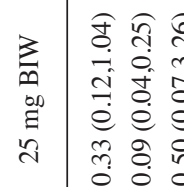

坚

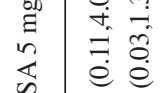

v

$\stackrel{0}{\circ}$

垔

6

西 $\bar{\sigma}$

के

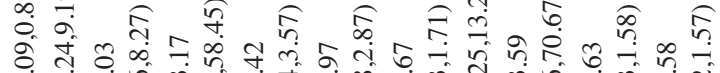

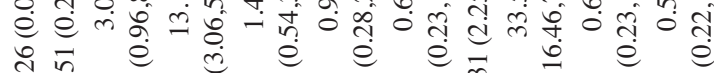
영 든

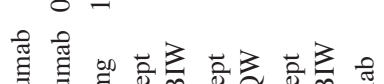

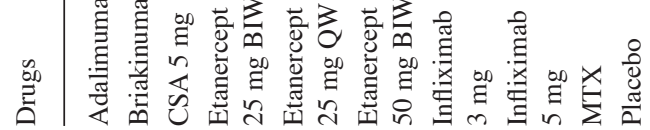

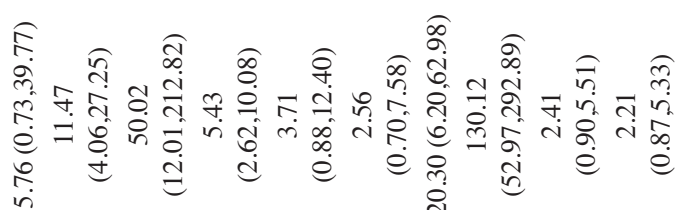

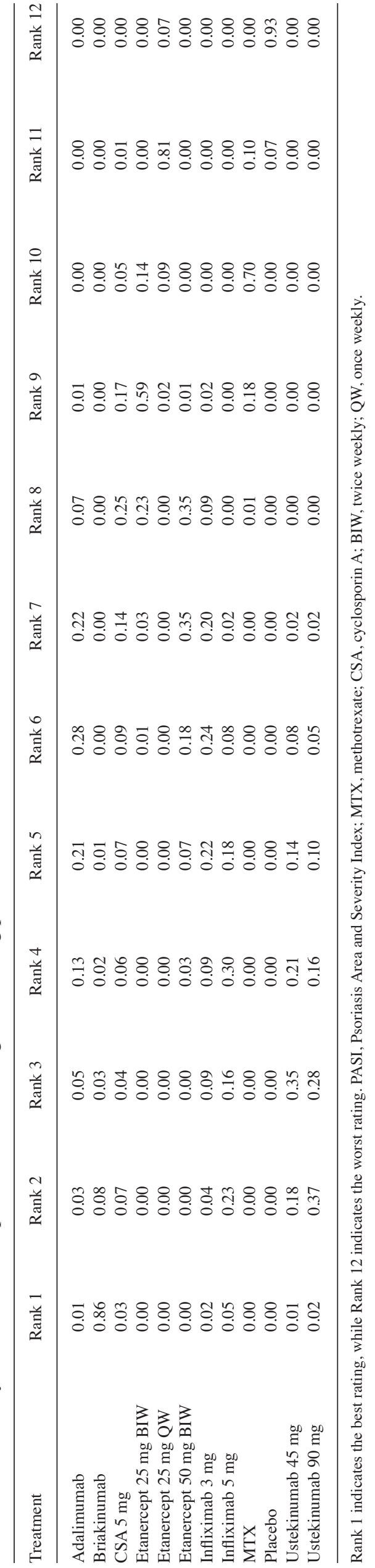




\section{References}

1. Parisi R, Symmons DP, Griffiths CE and Ashcroft DM Identification and Management of Psoriasis and Associated ComorbidiTy (IMPACT) project team: Global epidemiology of psoriasis: A systematic review of incidence and prevalence. J Invest Dermatol 133: 377-385, 2013.

2. Menter A, Gottlieb A, Feldman SR, Van Voorhees AS, Leonardi CL, Gordon KB, Lebwohl M, Koo JY, Elmets CA, Korman NJ, et al: Guidelines of care for the management of psoriasis and psoriatic arthritis: Section 1. Overview of psoriasis and guidelines of care for the treatment of psoriasis with biologics. J Am Acad Dermatol 58: 826-850, 2008.

3. Griffiths CE and Barker JN: Pathogenesis and clinical features of psoriasis. Lancet 370: 263-271, 2007.

4. Antoni CE, Kavanaugh A, Kirkham B, Tutuncu Z, Burmester GR, Schneider U, Furst DE, Molitor J, Keystone E, Gladman D, et al Sustained benefits of infliximab therapy for dermatologic and articular manifestations of psoriatic arthritis: Results from the infliximab multinational psoriatic arthritis controlled trial (IMPACT). Arthritis Rheum 52: 1227-1236, 2005.

5. Asahina A, Nakagawa H, Etoh T and Ohtsuki M; Adalimumab M04-688 Study Group: Adalimumab in Japanese patients with moderate to severe chronic plaque psoriasis: Efficacy and safety results from a Phase II/III randomized controlled study. J Dermatol 37: 299-310, 2010.

6. Griffiths C, Sterry W, Brock F, Dilleen M, Stefanidis D, Germain JM and Mallbris L: Pattern of response in patients with moderate-to-severe psoriasis treated with etanercept. Br J Dermatol 172: 230-238, 2015.

7. Sterry W, Ortonne JP, Kirkham B, Brocq O, Robertson D, Pedersen RD, Estojak J, Molta CT and Freundlich B: Comparison of two etanercept regimens for treatment of psoriasis and psoriatic arthritis: PRESTA randomised double blind multicentre trial. BMJ 340: c147, 2010.

8. Strober BE, Crowley JJ, Yamauchi PS, Olds M and Williams DA: Efficacy and safety results from a phase III, randomized controlled trial comparing the safety and efficacy of briakinumab with etanercept and placebo in patients with moderate to severe chronic plaque psoriasis. Br J Dermatol 165: 661-668, 2011.

9. Bagel J, Lynde C, Tyring S, Kricorian G, Shi Y and Klekotka P Moderate to severe plaque psoriasis with scalp involvement: A randomized, double-blind, placebo-controlled study of etanercept. J Am Acad Dermatol 67: 86-92, 2012.

10. Schäfer I, Hacker J, Rustenbach SJ, Radtke M, Franzke N and Augustin M: Concordance of the psoriasis area and severity index (PASI) and patient-reported outcomes in psoriasis treatment. Eur J Dermatol 20: 62-67, 2010.

11. Mrowietz U, Kragballe K, Reich K, Spuls P, Griffiths CE, Nast A, Franke J, Antoniou C, Arenberger P, Balieva F, et al: Definition of treatment goals for moderate to severe psoriasis: A European consensus. Arch Dermatol Res 303: 1-10, 2011.

12. Higgins JP, Altman DG, Gøtzsche PC, Jüni P, Moher D, Oxman AD, Savovic J, Schulz KF, Weeks L, Sterne JA, et al: The Cochrane Collaboration's tool for assessing risk of bias in randomised trials. BMJ 343: d5928, 2011.

13. Dias S, Welton NJ, Caldwell DM and Ades AE: Checking consistency in mixed treatment comparison meta-analysis. Stat Med 29: 932-944, 2010.

14. Barker J, Hoffmann M, Wozel G, Ortonne JP, Zheng H, van Hoogstraten $\mathrm{H}$ and Reich K: Efficacy and safety of infliximab vs. methotrexate in patients with moderate-to-severe plaque psoriasis: Results of an open-label, active-controlled, randomized trial (RESTORE1). Br J Dermatol 165: 1109-1117, 2011.

15. Cassano N, Miracapillo A, Coviello C, Loconsole F, Bellino M and Vena GA: Treatment of psoriasis vulgaris with the two-compound product calcipotriol/betamethasone dipropionate followed by different formulations of calcipotriol. Clin Drug Investig 26: 227-233, 2006

16. Flytstrom I, Stenberg B, Svensson A and Bergbrant IM: Methotrexate vs. ciclosporin in psoriasis: effectiveness, quality of life and safety. A randomized controlled trial. Br J Dermatol 158 $116-121,2008$

17. Gordon KB, Langley RG, Leonardi C, Toth D, Menter MA, Kang S, Heffernan M, Miller B, Hamlin R, Lim L, et al: Clinical response to adalimumab treatment in patients with moderate to severe psoriasis: Double-blind, randomized controlled trial and open-label extension study. J Am Acad Dermatol 55: 598-606, 2006.
18. Gottlieb AB, Evans R, Li S, Dooley LT, Guzzo CA, Baker D, Bala M, Marano CW and Menter A: Infliximab induction therapy for patients with severe plaque-type psoriasis: A randomized, double-blind, placebo-controlled trial. J Am Acad Dermatol 51: 534-542, 2004.

19. Gottlieb AB, Leonardi C, Kerdel F, Mehlis S, Olds M and Williams DA: Efficacy and safety of briakinumab vs. etanercept and placebo in patients with moderate to severe chronic plaque psoriasis. Br J Dermatol 165: 652-660, 2011.

20. Gottlieb AB, Matheson RT, Lowe N, Krueger GG, Kang S, Goffe BS, Gaspari AA, Ling M, Weinstein GD, Nayak A, et al: A randomized trial of etanercept as monotherapy for psoriasis. Arch Dermatol 139: 1627-1632, 2003.

21. Griffiths CE: Comparing biological therapies in psoriasis: Implications for clinical practice. J Eur Acad Dermatol Venereol 24: (Suppl 6): S10-S14, 2010.

22. Heydendael VM, Spuls PI, Opmeer BC, de Borgie CA, Reitsma JB, GoldschmidtWF,BossuytPM,Bos JDand deRieMA:Methotrexate versus cyclosporine in moderate-to-severe chronic plaque psoriasis. N Engl J Med 349: 658-665, 2003.

23. Ho SG, Yeung CK and Chan HH: Methotrexate versus traditional Chinese medicine in psoriasis: A randomized, placebo-controlled trial to determine efficacy, safety and quality of life. Clin Exp Dermatol 35: 717-722, 2010

24. Igarashi A, Kato T, Kato M, Song M and Nakagawa H; Japanese Ustekinumab Study Group: Efficacy and safety of ustekinumab in Japanese patients with moderate-to-severe plaque-type psoriasis: Long-term results from a phase $2 / 3$ clinical trial. J Dermatol 39: 242-252, 2012.

25. Laburte C, Grossman R, Abi-Rached J, Abeywickrama K and Dubertret L: Efficacy and safety of oral cyclosporin A (CyA; Sandimmun) for long-term treatment of chronic severe plaque psoriasis. Br J Dermatol 130: 366-375, 1994.

26. Leonardi CL, Kimball AB, Papp KA, Yeilding N, Guzzo C, Wang Y, Li S, Dooley LT and Gordon KB; PHOENIX 1 study investigators: Efficacy and safety of ustekinumab, a human interleukin-12/23 monoclonal antibody, in patients with psoriasis: 76-week results from a randomised, double-blind, placebo-controlled trial (PHOENIX 1). Lancet 371: 1665-1674, 2008

27. Leonardi CL, Powers JL, Matheson RT, Goffe BS, Zitnik R, Wang A and Gottlieb AB; Etanercept Psoriasis Study Group: Etanercept as monotherapy in patients with psoriasis. N Engl J Med 349: 2014-2022, 2003

28. McInnes IB, Kavanaugh A, Gottlieb AB, Puig L, Rahman P, Ritchlin C, Brodmerkel C, Li S, Wang Y, Mendelsohn AM, et al: Efficacy and safety of ustekinumab in patients with active psoriatic arthritis: 1 year results of the phase 3 , multicentre, double-blind, placebo-controlled PSUMMIT 1 trial. Lancet 382: 780-789, 2013.

29. Menter A, Feldman SR, Weinstein GD, Papp K, Evans R, Guzzo C, Li S, Dooley LT, Arnold C and Gottlieb AB: A randomized comparison of continuous vs. intermittent infliximab maintenance regimens over 1 year in the treatment of moderate-to-severe plaque psoriasis. J Am Acad Dermatol 56: 31 e1-e15, 2007.

30. Menter A, Tyring SK, Gordon K, Kimball AB, Leonardi CL, Langley RG, Strober BE, Kaul M, Gu Y, Okun M and Papp K: Adalimumab therapy for moderate to severe psoriasis: A randomized, controlled phase III trial. J Am Acad Dermatol 58: $106-115,2008$

31. Papp KA, Langley RG, Lebwohl M, Krueger GG, Szapary P, Yeilding N, Guzzo C, Hsu MC, Wang Y, Li S, et al: Efficacy and safety of ustekinumab, a human interleukin-12/23 monoclonal antibody, in patients with psoriasis: 52-week results from a randomised, double-blind, placebo-controlled trial (PHOENIX 2). Lancet 371: 1675-1684, 2008

32. Papp KA, Tyring S, Lahfa M, Prinz J, Griffiths CE, Nakanishi AM, Zitnik R, van de Kerkhof PC and Melvin L; Etanercept Psoriasis Study Group: A global phase III randomized controlled trial of etanercept in psoriasis: Safety, efficacy and effect of dose reduction. Br J Dermatol 152: 1304-1312, 2005.

33. Reich K, Nestle FO, Papp K, Ortonne JP, Evans R, Guzzo C, Li S, Dooley LT and Griffiths CE; EXPRESS study investigators: Infliximab induction and maintenance therapy for moderate-to-severe psoriasis: A phase III, multicentre, double-blind trial. Lancet 366: 1367-1374, 2005.

34. Revicki D, Willian MK, Saurat JH,Papp KA, Ortonne JP, Sexton C and Camez A: Impact of adalimumab treatment on health-related quality of life and other patient-reported outcomes: Results from a 16-week randomized controlled trial in patients with moderate to severe plaque psoriasis. Br J Dermatol 158: 549-557, 2008. 
35. Torii $\mathrm{H}$ and Nakagawa $\mathrm{H}$; Japanese Infliximab Study investigators: Infliximab monotherapy in Japanese patients with moderate-to-severe plaque psoriasis and psoriatic arthritis. A randomized, double-blind, placebo-controlled multicenter trial. J Dermatol Sci 59: 40-49, 2010.

36. Tsai TF, Ho JC, Song M, Szapary P, Guzzo C, Shen YK, Li S, Kim KJ, Kim TY, Choi JH, et al: Efficacy and safety of ustekinumab for the treatment of moderate-to-severe psoriasis: A phase III, randomized, placebo-controlled trial in Taiwanese and Korean patients (PEARL). J Dermatol Sci 63: 154-163, 2011

37. Tyring S, Gottlieb A, Papp K, Gordon K, Leonardi C, Wang A, Lalla D, Woolley M, Jahreis A, Zitnik R, et al: Etanercept and clinical outcomes, fatigue, and depression in psoriasis: Double-blind placebo-controlled randomised phase III trial. Lancet 367: 29-35, 2006.

38. van de Kerkhof PC, Segaert S, Lahfa M, Luger TA, Karolyi Z, Kaszuba A, Leigheb G, Camacho FM, Forsea D, Zang C, et al: Once weekly administration of etanercept $50 \mathrm{mg}$ is efficacious and well tolerated in patients with moderate-to-severe plaque psoriasis: A randomized controlled trial with open-label extension. Br J Dermatol 159: 1177-1185, 2008.

39. Yang HZ, Wang K, Jin HZ, Gao TW, Xiao SX, Xu JH, Wang BX, Zhang FR, Li CY, Liu XM, et al: Infliximab monotherapy for Chinese patients with moderate to severe plaque psoriasis: A randomized, double-blind, placebo-controlled multicenter trial. Chin Med J (Engl) 125: 1845-1851, 2012.

40. Cassano N, Loconsole F, Miracapillo A, Travaglini M, Digiuseppe MD, Congedo M, Galluccio A, Buquicchio R, Mastrandrea V, Filieri M, et al: Treatment of psoriasis with different dosage regimens of etanercept: Preliminary results from the Taranta plastic study group. Int J Immunopathol Pharmacol 23: 797-802, 2010.
41. Mussi A, Bonifati C, Carducci M, D'Agosto G, Pimpinelli F, D'Urso D, D'Auria L, Fazio M and Ameglio F: Serum TNF-alpha levels correlate with disease severity and are reduced by effective therapy in plaque-type psoriasis. J Biol Regul Homeost Agents 11: 115-118, 1997.

42. Cooper C, Shafran S, Greenbloom S, Enns R, Farley J, Hilzenrat N, Williams K, Elkashab M, Abadir N and Neuman M: Single-dose infliximab in hepatitis $\mathrm{C}$ genotype 1 treatment-naive patients with high serum tumour necrosis factor-alpha does not influence the efficacy of pegylated interferon alpha-2b/ribavirin therapy. Can J Gastroenterol Hepatol 28: 35-40, 2014.

43. Bedini C, Nasorri F, Girolomoni G, Pità Od and Cavani A: Antitumour necrosis factor-alpha chimeric antibody (infliximab) inhibits activation of skin-homing CD4+ and CD8+ T lymphocytes and impairs dendritic cell function. Br J Dermatol 157: 249-258, 2007.

44. Gottlieb AB, Chamian F, Masud S, Cardinale I, Abello MV, Lowes MA, Chen F, Magliocco M and Krueger JG: TNF inhibition rapidly down-regulates multiple proinflammatory pathways in psoriasis plaques. J Immunol 175: 2721-2729, 2005.

45. Steenholdt C, Svenson M, Bendtzen K, Thomsen OØ, Brynskov J and Ainsworth MA: Severe infusion reactions to infliximab: aetiology, immunogenicity and risk factors in patients with inflammatory bowel disease. Aliment Pharmacol Ther 34: 51-58, 2011.

46. Van Valkenhoef G, Tervonen T, Zwinkels T, de Brock B and Hillege H: ADDIS: A decision support system for evidence-based medicine. Decis Support Syst 55: 459-475, 2013. Attribution-NonCommercial-NoDerivatives 4.0 International (CC BY-NC-ND 4.0) License. 